\title{
Genetic Variability, Heritability and Genetic Advance for Horticultural Traits in Dolichos Beans of North East India
}

\author{
M. M. Shulee Ariina*, Yabi Gadi, Senjem Semba, \\ Naorem Johnson Singh and Ashwini Ananda \\ Department of Horticulture, SASRD, Nagaland University, India \\ *Corresponding author
}

\section{A B S T R A C T}

\begin{tabular}{l} 
Ke y w o r d s \\
Genetic, \\
Germplasms, \\
Heritability, \\
Variance and \\
Cluster \\
\hline Article Info \\
\hline $\begin{array}{l}\text { Accepted: } \\
\text { 12 October } 2020 \\
\text { Available Online: } \\
10 \text { November } 2020\end{array}$ \\
\hline
\end{tabular}

\section{Introduction}

Dolichos bean is one of the most ancient among the cultivated plants. In India it is mainly grown in North East India, Tamil Nadu, Karnataka, Madhya Pradesh, Uttar Pradesh and West Bengal. In general, two cultivated types viz., Lablab purpureus var. typicus and Lablab pupureus var. lignosus are under cultivation. Former is vegetable type cultivated for its soft and edible pods while the latter is cultivated as field bean for its dry seed as pulse crop. Both varieties are cross compatible. Dolichos bean has chromosome number $2 \mathrm{n}=2 \mathrm{x}=22,24$. The botanical name of Dolichos bean is Lablab purpureus $\mathrm{L}$. (Sweet). It is member of the family Leguminoseae, sub-family Faboideae, tribe phaseoleae and sub-tribe phaseolinae. It plays an important role in protein nourishment as it contains $20-30 \%$ protein on dry matter basis (Pawar and Prajapati, 2013). The rich legume biodiversity of India with 167 genera and 1141 species hold great promise in this regard (Mao and Hynniewta, 2000). In any crop improvement program, basic information with respect to variability present in the crop is essential. Yield being a complex trait, is 
collectively influenced by various component characters, which are polygenically inherited and highly influenced by environmental variations. Dolichos bean has unique position among legume vegetables (Biju et al., 2001). It is very difficult to judge whether observed variability is heritable or due to environment alone. Therefore, it is necessary to estimate relative amount of genetic and non-genetic variability exhibited by different traits using suitable parameters like genetic coefficient of variability, heritability and genetic advance. The knowledge of heritability is important for selection based crop improvement as it indicates the extent of character transmission in future generations. However, a measure of heritability alone does not give an idea about the expected gain in the next generation, but it has to be considered in conjunction with genetic advance. Thus, high yield can be achieved by selection of those characters that have high heritability coupled with genetic advance. Although this crop has originated in India and large number of indigenous strains is available, very little work has been done for genetic improvement of yield and quality. Hence, comprehensive germplasm collection and evaluation, identification of suitable genotypes and investigation of its value are essential followed by selection among diverse types and analysis of segregating generations. The primary objective of this investigation was to find out genetic variability parameters, heritability and genetic advance in the indigenous germplasms of Dolichos beans.

\section{Materials and Methods}

The present investigation was carried out at Vegetable Research Farm, Department of Vegetable Science, College of Horticulture and Forestry, Central Agricultural University, Pasighat, Arunachal Pradesh during the summer end of 2018. The geographical location of the research farm have an altitude of $153 \mathrm{~m}$ above mean sea level, latitude of $28^{\circ} 04^{\prime} \mathrm{N}$ and longitude of $95^{\circ} 22^{\prime} \mathrm{E}$. The climate of this area is humid $\left(30^{\circ} \mathrm{C}\right)$, subtropical and maximum rainfall occurs between June-September. The mean temperature from July to April ranges from $30.35^{\circ} \mathrm{C}$ to $23.1^{\circ} \mathrm{C}$. The soil is sandy loam with $\mathrm{pH} 6.7$ and organic carbon $2.1 \%$. The experiment was laid out in Randomized Block Design (RBD) with 22 genotypes with three replications. The genotypes are collected from farmers of 7 North East states of India where it has been grown indigenously. The pure, healthy, disease and insect free, vigorous and good quality Dolichos bean seeds were used for sowing. Seeds were sown at a depth of 2-3 $\mathrm{cm}$. Spacing between row to row and plant to plant was $3 \mathrm{~m}$ and $1.3 \mathrm{~m}$ respectively. Necessary plant protection measures with intercultural operations were carried out in accordance with the recommended package of practices. Observations were recorded on five randomly selected plants from each genotype in each replication namely Plant height $(\mathrm{cm})$, Number of branches per plant, Days to $50 \%$ flowering, Days to maturity, Number of flowers per cluster, Number of cluster per plant, Pod set $(\%)$, Pod length $(\mathrm{cm})$, Pod width $(\mathrm{cm})$, Pod weight $(\mathrm{g})$, Number of pods per cluster, Number of pods per plant, Number of seeds per pod, Pod yield per plant $(\mathrm{kg})$ and Pod yield per ha (q) respectively. Analysis of variance (ANOVA) and components of variance for individual character was carried out as per procedure adopted by Gomez and Gomez (1984) and the expected genetic advance resulted from selection of 5 percent superior individuals were worked out as suggested by Johnson et al., (1955).

\section{Results and Discussion}

The analysis of variance in the present investigation revealed significant differences among 22 Dolichos bean genotypes for all the traits studied and a wide range of variability 
was observed for plant height, number of branches per plant, days to $50 \%$ flowering, days to maturity, number of flowers per cluster, number of cluster per plant, pod set, pod length, pod width, pod weight, number of pods per cluster, number of pods per plant, number of seeds per pod, disease incidence, pest incidence, green pod crude protein, green pod crude fiber, pod yield per plant and pod yield per hectare which indicated the scope for selection of suitable initial breeding material for further crop improvement. Similar results were also been reported by Dewangan et al., (2017), Kushwah et al., (2016), Parmar et al., (2013) and Pan et al., (2001) under different environmental conditions.

A wide range of variability was observed in the genotypes. However, the information based on the range provides rough estimates of the degree of the variation present in the materials and is more reliable if based on coefficients of variability. For all the characters studied, phenotypic coefficients of variability were higher in magnitude than genotypic coefficients of variability, though difference was very less in majority of the cases. Thus, showing that these traits are less influenced by environmental factors. Coefficients of variability varied in magnitude from character to character (either low or moderate or high). Therefore, it indicated that there was a great diversity in the experimental material used.

In the present investigation, the high genotypic coefficient of variation (GCV) was observed for pod yield per hectare, pod yield per plant, number of pods per plant. This reflects greater genetic variability among the genotypes for these characters for making further improvement by selection. These results were in conformity with Patil et al., (2015) and Pan et al., (2001). However, the moderate GCV were recorded in case of days to $50 \%$ flowering, protein content and days to maturity. The estimates of these parameters are in line with the findings of Dewangan et al., (2017) and Chaudhari et al., (2013). The lowest estimates of GCV were recorded in case of number of seeds per pod and pod set. The estimates of these parameters are in line with the findings of Patil et al., (2015) and Pawar and Prajapati (2013).

Wide variability present in experimental materials suggested that there are ample scopes for bringing out improvement in these characters. The genotypic coefficient of variation does not offer full scope to estimate the variations that are heritable and therefore, estimation of heritability becomes necessary. The effectiveness of selection depends upon genetic advance of the character selected along with heritability. In the present investigation the estimates of heritability (broad sense) was high for most characters studied. This indicated that selection for these characters will be effective as phenotype is a true representative of genotype. Heritability estimates in broad sense will be reliable if accompanied by high genetic advance (Burton and de Vane, 1953).

In the present investigation, high heritability estimates (broad sense) was recorded high for all the characters under study except number of seeds per pod (49.78) which had moderate heritability. Highest heritability was recorded in pod yield per plant (99.99) and pod yield per hectare (99.99). These findings are in agreement with Chaudhari et al., (2013) and Singh et al., (2011). High heritability for different traits indicated that large proportion of phenotypic variance has been attributed to genotypic variance and suggested that selection could be made for these traits on the basis of phenotypic expression. Burton (1952) also suggested that a genotypic coefficient of variation along with high heritability gives clear picture of gain to be expected from selection (Table 1 and 2). 
Table.1 Estimates of variability, heritability, genetic advance and GA as percent of mean for yield attributes in Indian bean germplasm

\begin{tabular}{|c|c|c|c|c|c|c|c|c|c|c|c|}
\hline \multirow[t]{2}{*}{ S.N. } & \multirow[t]{2}{*}{ Characters } & \multirow[t]{2}{*}{$\begin{array}{l}\operatorname{Mean} \pm \\
\operatorname{SE}(m)\end{array}$} & \multicolumn{2}{|c|}{ Range } & \multicolumn{2}{|c|}{ Variance } & \multicolumn{2}{|c|}{$\begin{array}{l}\text { Coefficient of } \\
\text { variability }(\%)\end{array}$} & \multirow[t]{2}{*}{$\begin{array}{l}\text { Heritabili } \\
\text { ty } \%\end{array}$} & \multirow[t]{2}{*}{$\begin{array}{c}\text { Genetic } \\
\text { advance }\end{array}$} & \multirow{2}{*}{$\begin{array}{l}\text { Genetic advance } \\
\text { as \% of mean } \\
\text { (Genetic gain) }\end{array}$} \\
\hline & & & Min & Max & Phenotypic & Genotypic & PCV & GCV & & & \\
\hline 1. & Plant Height (cm) & $296.06 \pm 4.27$ & 44.33 & 378.67 & 6970.16 & 6965.88 & 28.20 & 28.19 & 99.94 & 171.87 & 58.05 \\
\hline 2. & $\begin{array}{c}\text { Number of branches per } \\
\text { plant }\end{array}$ & $5.05 \pm 0.00$ & 3.48 & 8.61 & 1.6224 & 1.6221 & 25.204 & 25.201 & 99.98 & 2.62 & 51.90 \\
\hline 3. & Days to $50 \%$ flowering & $102.93 \pm 1.69$ & 65.67 & 122.3 & 331.17 & 329.48 & 17.67 & 17.63 & 99.49 & 37.29 & 36.23 \\
\hline 4. & Days to maturity & $130.36 \pm 1.96$ & 90.33 & 154.67 & 356.58 & 354.62 & 14.48 & 14.44 & 99.45 & 38.68 & 29.67 \\
\hline 5. & $\begin{array}{c}\text { Number of flowers per } \\
\text { cluster }\end{array}$ & $15.93 \pm 0.086$ & 6.83 & 22.03 & 15.37 & 15.28 & 24.61 & 24.54 & 99.44 & 8.03 & 50.41 \\
\hline 6. & Number of cluster per plant & $11.64 \pm 0.033$ & 4.10 & 16.73 & 10.71 & 10.68 & 28.10 & 28.06 & 99.69 & 6.72 & 57.71 \\
\hline 7. & Pod set \% & $44.36 \pm 1.09$ & 37.72 & 48.17 & 11.61 & 10.51 & 7.68 & 7.31 & 90.56 & 6.35 & 14.33 \\
\hline 8. & Pod length (cm) & $10.40 \pm 0.08$ & 5.53 & 14.43 & 6.08 & 6.00 & 23.71 & 23.56 & 98.68 & 5.01 & 48.21 \\
\hline 9. & Pod width (cm) & $2.51 \pm 0.007$ & 0.83 & 3.07 & 0.52 & 0.51 & 28.79 & 28.58 & 98.52 & 1.46 & 58.44 \\
\hline 10 & Pod weight (g) & $7.76 \pm 0.04$ & 3.07 & 12.62 & 8.94 & 8.90 & 38.52 & 38.43 & 99.49 & 6.13 & 78.96 \\
\hline 11. & Number of pods per cluster & $6.94 \pm 0.01$ & 3.03 & 10.33 & 3.26 & 3.25 & 26.02 & 25.97 & 99.55 & 3.70 & 53.37 \\
\hline 12. & Number of pods per plant & $85.58 \pm 18.85$ & 12.43 & 172.90 & 1568.48 & 1549.62 & 46.27 & 45.99 & 98.80 & 80.60 & 94.17 \\
\hline 13. & Number of seeds per pod & $4.74 \pm 0.17$ & 3.83 & 5.67 & 0.34 & 0.17 & 12.33 & 8.70 & 49.78 & 0.60 & 12.65 \\
\hline 14. & Pod yield per plant (Kg) & $0.674 \pm 22.6$ & 0.087 & 2.181 & 228539.05 & 228516.37 & 70.914 & 70.911 & 99.99 & 984.70 & 146.06 \\
\hline 15. & Pod yield per hectare (q) & $19.2 \pm 0.00$ & 2.487 & 62.320 & 1.8656 & 1.8654 & 70.929 & 70.926 & 99.99 & 2.81 & 146.10 \\
\hline
\end{tabular}

Table.2 Estimates of variability, heritability, genetic advance and GA as percent of mean for quality attributes in Indian bean germplasm

\begin{tabular}{|c|c|c|c|c|c|c|c|c|c|c|c|}
\hline \multirow[t]{2}{*}{ S.N. } & \multirow[t]{2}{*}{ Characters } & \multirow{2}{*}{$\begin{array}{l}\text { Mean } \pm \\
\text { SE }(m)\end{array}$} & \multicolumn{2}{|c|}{ Range } & \multicolumn{2}{|c|}{ Variance } & \multicolumn{2}{|c|}{$\begin{array}{c}\text { Coefficient of } \\
\text { variability }(\%)\end{array}$} & \multirow{2}{*}{$\begin{array}{l}\text { Heritabi } \\
\text { lity \% }\end{array}$} & \multirow{2}{*}{$\begin{array}{l}\text { Genetic } \\
\text { advance }\end{array}$} & \multirow{2}{*}{$\begin{array}{c}\text { Genetic } \\
\text { advance as \% } \\
\text { of mean } \\
\text { (Genetic } \\
\text { gain) }\end{array}$} \\
\hline & & & Min & Max & Phenotypic & Genotypic & PCV & GCV & & & \\
\hline 1. & $\begin{array}{l}\text { Green pod crude protein } \\
\text { (mg/100g) }\end{array}$ & $17287.9 \pm 0.09$ & 14466.7 & 25200.0 & 8.57 & 8.47 & 16.93 & 16.84 & 98.90 & 5.96 & 34.50 \\
\hline 2. & Green pod crude fiber $(\%)$ & $0.26 \pm 0.00$ & 0.067 & 0.57 & 0.0142 & 0.0140 & 44.57 & 44.26 & 98.61 & 0.24 & 90.55 \\
\hline
\end{tabular}


The high heritability values for yield and component characters are in line with the findings of Dewangan et al., (2017), Kushwah et al., (2016), Patil et al., (2015), Pawar et al., (2013) and Salim et al., (2013). Further, Johnson et al., (1955) reported that high heritability estimates along with high genetic gain were useful than heritability alone for effective selection. Similarly, in the present study the characters like plant height, number of branches per plant, days to $50 \%$ flowering, days to maturity, number of flowers per cluster, number of cluster per plant, pod length, pod width, pod weight, number of pods per cluster, number of pods per plant, green pod crude protein, green pod crude fiber, pod yield per plant and pod yield per hectare recorded high heritability with high genetic advance as percentage of mean which indicated that these characters are under additive gene effects and hence these characters are more reliable for effective selection (Panse, 1957). These findings were in agreement with Dewangan et al., (2017) for days to maturity and number of flowers per cluster, Kushwah et al., (2016) for plant height, pod width, pod yield per plant, pod yield per hectare, pod weight and fiber content, Chaudhari et al., (2013) for pod yield per plant, number of branches per plant, number of pods per cluster, number of pods per plant and protein content, Parmar et al., (2013) for days to $50 \%$ flowering, Salim et al., (2013) for number of seeds per pod, Latha et al., (2009) for number of branches per plant, pod length, number of pods per plant, pod yield per plant and Rathnaiah (1986) for number of inflorescence per plant.

High heritability coupled with moderate genetic gain was observed for pod set which indicated that these characters are under nonadditive gene effects and selection for these characters will be less effective. Such traits are more under the influence of environment and do not respond to selection. These findings were similar with Patil et al., (2015) for pod set. However, the breeder should adopt suitable breeding methodology to utilize both additive and non-additive gene effects simultaneously, since varietal development will go a long way in the breeding programmes in case of Dolichos bean.

\section{Acknowledgement}

The authors are thankful to Department of Basic Science Humanities, College of Horticulture and Forestry, Central Agricultural University, Pasighat, Arunachal Pradesh, for providing all kinds of help during the present analysis.

\section{References}

Biju, M.G., Prasanna, K.P. and Rajan, S. (2001). Genetic divergence in hyacinth bean. Veg. Sci., 28(2): 163-164.

Burton, G.W. (1952). Quantitative inheritance in grasses. In: Proceedings of $6^{\text {th }}$ International Grassland Congress, Pennsylvania state college, USA, 1(2): 227-285.

Burton, G.W. and de Vane, E.H. (1953). Estimating heritability in tall fiscue (Festuca arundinacea) from replicated clonal material. Agron. J., 45(10): 478481.

Chaudhari, P.P., Patel, A.I., Kadam, Y.R. and Patel, J.M. (2013). Variability, correlation and path analysis study in vegetable Indian bean [Lablab purpureus (L.) sweet]. Crop Res., 45(1,2,3): 229-236.

Dewangan, R., Bahadur, V., Choyal, P., Ramesh, Xaxa, S., Singh, V.P., Sachan, S. and Kerketta, A. (2017). Study on genetic variability, heritability and genetic advance in Dolichos bean (Lablab purpureus L.) genotypes. Int. J. Curr. Microbiol. App. Sci., 6(8): 3228- 
3232.

Gomez, A.K. and Gomez, A.A. (1984). Statistical procedures for agricultural research. $2^{\text {nd }}$ edition. Wiley India Private Limited, Ansari road, Daryaganj, New Delhi, pp. 134-138.

Johnson, H.W., Robinson, H.F. and Comstock, R.E. (1955). Estimate of genetic and environmental variability in soybeans. Agron. J., 47(7): 314-318.

Kushwah, S.S., Singh, O.P., Naruka, I.S. and Choudhary, J. (2016). Studies on genetic variability and character association in Indian bean [Lablab purpureus (L.) Sweet]. Legume Res., 39(3): 336-342.

Latha, M., Mani, S., Markose, B.L., Abraham, Z., Nair, A., Hanuman and Misra, S.K. (2009). Collection and characterization of field bean (Lablab purpureus L. sweet var. purpureus). Indian J. Plant Genet. Resour., 22(2): 93-97.

Mao, A.A. and Hynniewta, T.M. (2000). Floristic diversity of North East India. $J$. Assam Sci. Soc., 41(4): 255-266.

Pan, R.S., Singh, A.K. and Rai, M. (2001). Genetic variability in Dolichos bean. Indian J. Genet. Resour., 14: 220-222.

Panse, V.S. (1957). Genetics of quantitative characters in relation to plant breeding. Indian J. Genet., 17: 318-328.

Parmar, A.M., Singh, A.P., Dhillon, N.P.S. and Jamwal, M. (2013). Genetic variability studies for morphological and yield traits in dolichos bean (Lablab purpureus L.). World J. Agric. Sci., 9(1): 24-28.

Patil, B.T., Inamdar, A.F., Bhalekar, M.N. and Shinde, K.G. (2015). Genetic variability and heritability studies in pole type Indian bean (Lablab purpureus L. Sweet). Veg. Sci., 42(1): 103-104.

Pawar, R.M. and Prajapati, R.M. (2013). Genetic variability, correlation and path analysis in Indian bean (Lablab purpureus L. Sweet). Int. J. Agric. Sci., 9(2): 615-619.

Rathnaiah, T.R. (1986). The study of variability and formulation of selection indices for vegetable yield in field bean (Lablab purpureus L. Sweet). Mysore J. Agric Sci., 19(3): 216.

Salim, M., Hossain, S., Alam, S., Rashid, J.A. and Islam, S. (2013). Variability, correlation and path analysis in Lablab bean (Lablab purpureus L.). Bangladesh J. Agric. Res., 38(4): 705717.

Singh, P.K., Rai, N., Lal, H., Bhardwaj, D.R., Singh, R. and Singh, A.P. (2011). Correlation, path and cluster analysis in Hyacinth bean (Lablab purpureus L. Sweet). J. Agric. Tech., 7(4): 11171124.

\section{How to cite this article:}

Shulee Ariina, M.M., Yabi Gadi, Senjem Semba, Naorem Johnson Singh and Ashwini Ananda. 2020. Genetic Variability, Heritability and Genetic Advance for Horticultural Traits in Dolichos Beans of North East India. Int.J.Curr.Microbiol.App.Sci. 9(11): 1630-1635. doi: https://doi.org/10.20546/ijcmas.2020.911.194 